\title{
Pemanfaatan Tepung Tulang Ikan Tenggiri untuk Meningkatkan Daya Terima dan Kandungan Kalsium Biskuit dan Opak Singkong
}

\section{Utilization of Mackerel Fish Bone Flour to Increase the Acceptability and Calcium Content of Biscuits and Cassava Opak}

\author{
Sefanadia Putri ${ }^{1, \bigotimes}$, Arie Nugroho ${ }^{1}$ \\ ${ }^{1}$ Jurusan Gizi, Politeknik Kesehatan Tanjung Karang, Indonesia \\ ${ }^{\bowtie}$ Corresponding authors: sefanadia@poltekkes-tjk.ac.id
}

\begin{abstract}
Kata kunci:
Tepung tulang ikan tengiri,

Kandungan kalsium biskuit,

Kandungan kalsium opak singkong.
\end{abstract}

\section{Keyword:}

Tengiri fish bone meal, Calcium content of

biscuits,

Calcium content of cassava opaque.

\begin{abstract}
Abstrak
Latar belakang: Provinsi Lampung merupakan salah satu provinsi yang memiliki potensi sumber daya perikanan laut cukup besar. Tujuan: Tepung tulang ikan tenggiri memiliki potensi untuk dikembangkan karena tepung tulang ikan tenggiri mengandung tinggi kalsium. Metode: Penelitian ini merupakan penelitian eksperimen laboratorium. Perlakuan dilakukan dengan penambahan tepung tulang ikan kedalam produk biskuit dan opak. Penambahan tepung tulang ikan pada setiap produk terdiri dari 6 taraf dengan konsentrasi yang berbeda-beda dan $3 \mathrm{kali}$ pengulangan. Analisis data menggunakan analisis univariat dan analisis bivariat menggunakan uji analysis of variance (Anova). Hasil: Hasil penelitian menunjukkan bahwa konsentrasi penambahan tepung tulang ikan tenggiri yang paling disukai oleh Panelis pada produk biskuit pada formula 3, yaitu biskuit dengan konsentrasi penambahan tepung tulang ikan tenggiri sebesar 5\% dan produk opak singkong pada formula 3, yaitu opak singkong dengan konsentrasi penambahan tepung tulang ikan tenggiri sebesar $20 \%$. Kandungan kalsium pada produk biskuit formula $3(5 \%)$ sebesar $0,72 \%$, opak singkong formula $3(20 \%)$ sebesar $0,131 \%$. Simpulan: Panelis paling menyukai produk biskuit dengan penambahan tepung tulang ikan tenggiri $5 \%$ dan kandungan kalsium $0,72 \%$, sedangkan Opak singkong yang disukai dengan penambahan tepung tulang ikan tenggiri $20 \%$ yang mengandung kalsium $0,131 \%$.
\end{abstract}

\begin{abstract}
s
Background: Lampung Province is one of the provinces that has considerable marine fishery resource potential. Purpose: Mackerel bone flour has the potential to be developed because the mackerel fish bone meal contains high calcium. Methods: This research is a laboratory experimental study. The treatment is done by adding fish bone meal into biscuits and opaque products. Addition of fish bone meal to each product consists of 6 levels with different concentrations and 3 repetitions. Data analysis using univariate analysis and bivariate analysis using analysis of variance (Anova) test. Results: The results showed that the concentration of addition of mackerel fish bone meal most favored by Panelists on biscuit products in formula 3, namely biscuits with the addition of mackerel bone flour concentration of $5 \%$ and cassava opaque products in formula 3, namely cassava opaque with additional concentrations mackerel fish bone meal by $20 \%$. Calcium content in formula $3(5 \%)$ biscuits is $0.72 \%$, cassava formula $3(20 \%)$ is $0.131 \%$. Conclusion: Panelists most like biscuit products with the addition of 5\% mackerel fish bone flour and $0.72 \%$ calcium content, while cassava Opak is preferred with the addition of $20 \%$ mackerel fish bone meal containing $0.131 \%$ calcium.
\end{abstract}

Copyright (C) 2019 Jurnal Kesehatan Metro Sai Wawai. All rights reserved. 


\section{Pendahuluan}

Stunting dan osteoporosis masih menjadi masalah gizi yang sampai saat ini belum tertangani dengan baik. Berdasarkan data Riskesdas Provinsi Lampung tahun 2013 pravalensi gizi kurang sebesar 11,9\%, gizi buruk 6,9\% dan prevalensi dengan kategori pendek sebesar $15 \%$, dan gizi kurus sebesar 6,2 \% (Badan Litbangkes Kemenkes R.I, 2013). World Health Organization (WHO) memasukan osteoporosis dalam daftar 10 penyakit degeratif utama di dunia. Di Indonesia prevalensi osteoporosis berdasarkan data pusat penelitian dan pengembangan Gizi Departemen Kesehatan Republik Indonesia dalam penderita osteoporosis telah mencapai $19,7 \%$ dan berada di urutan ke enam terbesar di Cina. Salah satu cara menanggulangi masalah stunting dan osteoporosis yaitu dengan meningkatkan kandungan zat gizi kalsium dan protein pada produk makanan dan minuman, pemberian suplementasi vitamin dan mineral, peningkatan pengetahuan terkait makanan dan gizi pada orang tua asuh (Depkes RI, 2006). Makanan yang banyak dijumpai sebagian besar merupakan makanan yang tinggi kalori, tinggi garam atau msg, tinggi gula dan kurang bermanfaat bagi kesehatan (Nugrahani, 2014).

Provinsi Lampung merupakan salah satu provinsi yang memiliki potensi sumber daya perikanan laut cukup besar. Kota Bandar Lampung merupakan daerah yang memiliki potensi perikanan dengan jumlah produksi 31.230 ton pada tahun 2016 (Badan Pusat Statistik Provinsi Lampung, 2017). Menurut Kelautan dan Perikanan kota Bandar Lampung tahun 2014 bahwa ikan tenggiri termasuk ikan yang tinggi produksinya di Lampung. Selama tahun 2014 produksi ikan tenggiri di Bandar Lampung yaitu sebanyak $1576,8 \mathrm{~kg}$. Ikan tenggiri banyak dimanfaatkan sebagai bahan pempek, bakso dan lainnya, namun hal itu menyisakan tulang ikan yang sampai saat ini tulang ikan belum dapat dimanfaatkan secara optimal dan hanya menjadi sisa dari pembuatan ikan giling. Kandungan kalsium pada tulang ikan cukup tinggi dan tulang ikan dapat dimanfaatkan menjadi tepung yang kaya akan kalsium.

Makanan bergizi tidak selalu mahal karena dapat dijumpai pada beragam jenis biji-bijian, buah dan sayur segar yang kaya vitamin dan mineral yang bermanfaat menjaga kesehatan (Waluyani, 2012). Biskuit dan opak merupakan salah satu makanan yang disukai oleh seluruh kalangan usia karena rasanya enak, bervariasi, bentuk beraneka ragam, harga reltif murah, cukup mengenyangkan, hingga kandungan gizi yang lengkap. Tetapi biskuit dan opak yang beredar di pasaran mempunyai kadar protein dan kalsium yang relatif rendah sehingga perlu dilakukan upaya fortifikasi pada biskuit dengan bahan pangan berprotein dan kalsium tinggi seperti tepung tulang ikan tenggiri. Berdasarkan uraian di atas, maka penulis ingin mengembangkan suatu produk dengan memanfaatkan tulang ikan tenggiri untuk dikembangkan menjadi makanan dan minuman yang bergizi sehingga dapat meningkatkan nilai ekonomi tulang ikan tenggiri tersebut. Diharapkan produk tersebut dapat meningkatkan kandungan kalsium guna mencegah timbulnya penyakit osteoporosis, serta aman dikonsumsi oleh semua kalangan. Artikel ini memberikan informasi dari hasil penelitian yang bertujuan memperoleh formula yang disukai Panelis dari perbedaan konsentrasi penambahan tepung tulang tenggiri yang paling disukai pada produk biskuit dan opak serta diketahui kandungan kalsium pada produk biskuit dan opak dengan penambahan tepung tulang ikan tenggiri.

\section{Metode}

Penelitian ini merupakan penelitian eksperimen dengan menggunakan data sekunder. Perlakuan yaitu penambahan tepung tulang ikan kedalam 2 produk meliputi : biscuit dan opak. Penambahan tepung tulang ikan pada setiap produk terdiri dari 6 taraf dengan konsentrasi yang berbeda-beda dan 3 kali pengulangan. Penambahan tepung tulang ikan pada produk biskuit terdiri dari 6 taraf, yaitu yaitu $0 \%(\mathrm{~F} 1)$, 2,5\% (F2), $5 \%$ (F3), 7,5\% (F4), 10\% (F5), 12,5\% (F6). Penambahan tepung tulang ikan pada produk opak 
singkong dihitung dari total singkong terdiri dari 6 taraf, yaitu 0\% (F1), 10\% (F2), 20\% (F3), 30\% (F4), $40 \%$ (F5) dan 50\% (F6).

Subyek penelitian ini adalah biscuit dan opak singkong yang dibuat dengan penambahan tepung tulang ikan. Tulang ikan yang digunakan adalah tulang ikan tenggiri yang banyak dijumpai di pasar ikan Gudang Lelang, Bandar Lampung. Penelitian dilakukan di Laboratorium Penyelenggaraan Makanasn Jurusan Gizi Politeknik Kesehatan Tanjungkarang. Analisis kadar kalsium di lakukan di Laboratorium Politeknik Negeri Lampung.

Analisis data yang digunakan adalah analisis univariat, yaitu dengan menampilkan hasil penilaian berupa nilai rata-rata (mean) dari masing-masing variabel untuk mengetahui distribusi frekuensi dari tabeltabel yang diamati sehingga dapat mengetahui karakteristik atau gambaran dari semua variabel, yaitu warna, aroma, rasa, tekstur /konsistensi produk dengan menggunakan tampilan berupa tabel atau grafik. Kemudian analisis bivariat menggunakan uji analysis of variance (Anova). Apabila terdapat pengaruh analisis ragam maka dilanjutkan dengan uji lanjut DMRT (Duncan Multiple Range Test). Analisis kandungan kalsium menggunakan univariat dan data akan disajikan dalam bentuk tabel atau grafik dalam satuan persen $(\%)$.

\section{Hasil}

\section{Uji organoleptik}

\section{Biskuit}

Uji organoleptik pada biskuit menggunakan metode uji hedonik, dimana pengujian dilakukan dengan cara mengisi kuesioner uji organoleptik yang meliputi warna, aroma, rasa, tekstur dan penerimaan keseluruhan terhadap keenam produk biskuit yang di tambahkan tepung tulang ikan tenggiri. Hasil penilaian organoleptik biskuit yang ditambahkan tepung tulang ikan tenggiri dapat dilihat pada tabel 1 .

Tabel 1.

Uji organoleptik biskuit

\begin{tabular}{lccccc}
\hline \multicolumn{1}{c}{ Variabel Biskuit } & Warna & Rasa & Aroma & Tekstur & $\begin{array}{c}\text { Penerimaan } \\
\text { keseluruhan }\end{array}$ \\
\hline Formula 1 & $3,60(\mathrm{a})$ & $3,60(\mathrm{c})$ & $3,72(\mathrm{c})$ & $3,76(\mathrm{c})$ & $3,87(\mathrm{~b})$ \\
Formula 2 & $3,60(\mathrm{a})$ & $3,48(\mathrm{bc})$ & $3,72(\mathrm{c})$ & $3,55(\mathrm{~b})$ & $3,92(\mathrm{~b})$ \\
Formula 3 & $3,60(\mathrm{a})$ & $4,08(\mathrm{~d})$ & $3,96(\mathrm{~d})$ & $4,01(\mathrm{~d})$ & $4,21(\mathrm{c})$ \\
Formula 4 & $3,68(\mathrm{a})$ & $3,24(\mathrm{~b})$ & $3,84(\mathrm{~cd})$ & $3,31(\mathrm{a})$ & $3,48(\mathrm{a})$ \\
Formula 5 & $3,60(\mathrm{a})$ & $3,44(\mathrm{bc})$ & $3,48(\mathrm{~b})$ & $3,72(\mathrm{c})$ & $3,60(\mathrm{a})$ \\
Formula 6 & $3,60(\mathrm{a})$ & $3,00(\mathrm{a})$ & $2,48(\mathrm{a})$ & $3,32(\mathrm{a})$ & $3,44(\mathrm{a})$ \\
P-value & 0,892 & 0,0005 & 0,0005 & 0,0005 & 0,0005 \\
\hline
\end{tabular}

Keterangan: huruf yang berbeda kearah kolom menunjukkan berbeda nyata menurut uji DMRT pada taraf $5 \%$.

Hasil uji statistik didapat nilai $\mathrm{p}$ untuk warna sebesar $=0,892$, sedangkan nilai $\mathrm{p}$ untuk rasa, aroma, tekstur dan penerimaan keseluruhan sebesar $=0,005$. Hasil uji statistik menyatakan bahwa uji organoleptik biskuit yang meliputi rasa, aroma, tekstur dan penerimaan keseluruhan pada alpha 5\% terdapat perbedaan secara nyata. Hasil uji lanjut DMRT menunjukkan bahwa warna biskuit semua formula tidak berbeda nyata.Variabel rasa, hasil uji lanjut DMRT menunjukkan bahwa terdapat perbedaan nyata biskuit antar formula. Variabel aroma, hasil uji lanjut DMRT menunjukkan bahwa aroma biskuit formula 1 tidak berbeda nyata dengan formula 2 dan 4, serta formula 3 tidak berbeda nyata dengan formula 4, sedangkan aroma biskuit pada formula 6 berbeda nyata antar formula. Variabel tekstur, hasil uji lanjut DMRT menunjukkan bahwa tekstur biskuit formula 1 tidak berbeda nyata dengan formula 5, Formula 2 berbeda nyata antar formula, sedangkan formula 4 tidak berbeda nyata dengan formula 6 . Variabel penerimaan 
keseluruhan, hasil uji lanjut DMRT menunjukkan bahwa boskuit formula 3 berbeda nyata antar formula, formula 1 tidak berbeda nyata dengan formula 2, sedangkan formula 4 tidak berbdea nyata dengan formula 5 dan 6.

\section{Opak singkong}

Uji organoleptik pada opak singkong menggunakan metode uji hedonik, dimana pengujian dilakukan dengan cara mengisi kuesioner uji organoleptik yang meliputi warna, aroma, rasa, tekstur dan penerimaan keseluruhan terhadap keenam produk opak singkong yang di tambahkan tepung tulang ikan tenggiri. Hasil uji statistik menyatakan bahwa uji organoleptik yang meliputi rasa, tekstur dan penerimaan keseluruhan pada alpha 5\% terdapat perbedaan secara nyata. Sedangkan variable warna dan aroma tidak terdapat perbedaan yang nyata.

Tabel 2.

Uji organoleptik opak singkong

\begin{tabular}{lccccc}
\hline $\begin{array}{c}\text { Variabel Opak } \\
\text { Singkong }\end{array}$ & Warna & Rasa & Aroma & Tekstur & $\begin{array}{c}\text { Penerimaan } \\
\text { Keseluruhan }\end{array}$ \\
\hline Formula 1 & $4,13(\mathrm{a})$ & $3,87(\mathrm{bc})$ & $3,71(\mathrm{a})$ & $3,53(\mathrm{a})$ & $3,97(\mathrm{c})$ \\
Formula 2 & $4,08(\mathrm{a})$ & $3,83(\mathrm{bc})$ & $3,76(\mathrm{a})$ & $3,56(\mathrm{ab})$ & $3,92(\mathrm{bc})$ \\
Formula 3 & $4,12(\mathrm{a})$ & $3,89(\mathrm{c})$ & $3,85(\mathrm{a})$ & $3,63(\mathrm{abc})$ & $3,99(\mathrm{c})$ \\
Formula 4 & $4,07(\mathrm{a})$ & $3,61(\mathrm{ab})$ & $3,85(\mathrm{a})$ & $4,69(\mathrm{~d})$ & $3,71(\mathrm{ab})$ \\
Formula 5 & $3,89(\mathrm{a})$ & $3,55(\mathrm{a})$ & $3,79(\mathrm{a})$ & $3,84(\mathrm{bc})$ & $3,64(\mathrm{a})$ \\
Formula 6 & $3,87(\mathrm{a})$ & $3,47(\mathrm{a})$ & $3,65(\mathrm{a})$ & $3,81(\mathrm{bc})$ & $3,52(\mathrm{a})$ \\
P-value & 0,187 & 0,002 & 0,443 & 0,0005 & 0,0005 \\
\hline
\end{tabular}

Keterangan: huruf yang berbeda kearah kolom menunjukkan berbeda nyata menurut uji DMRT pada taraf $5 \%$.

Hasil uji lanjut DMRT menunjukkan bahwa warna dan aroma opak singkong semua formula tidak berbeda nyata.Variabel rasa, hasil uji lanjut DMRT menunjukkan bahwa terdapat perbedaan nyata rasa opak singkong formula 1, 2 dan 3 sedangkan formula 4 berbeda nyata dengan formula 5 dan 6 . Variabel tekstur, hasil uji lanjut DMRT menunjukkan bahwa tidak terdapat perbedaan nyata tekstur opak singkong formula 1,2, 3, 5 dan 6 sedangkan tekstur opak singkong formula 4 berbeda nyata antar formula. Variabel penerimaan keseluruhan, hasil uji lanjut DMRT menunjukkan bahwa terdapat perbedaan nyata penerimaan keseluruhan opak singkong formula 1,2 dan 3 sedangkan formula 4 berbeda nyata dengan formula 5 dan 6.

Tabel 3.

Kandungan zat gizi tepung tulang ikan tenggiri

\begin{tabular}{lc}
\hline \multicolumn{1}{c}{ Kandungan Gizi } & Persentase (\%) \\
\hline Air & 1,28 \\
Abu & 27,49 \\
Protein & 40,35 \\
Lemak & 21,5 \\
Serat Kasar & 4,57 \\
Karbohidrat & 4,77 \\
Kalsium & 0,403 \\
\hline
\end{tabular}

\section{Analisis kandungan kalsium}

Pada penelitian pendahuluan, dilakukan Analisis kandungan gizi tepung tulang ikan tenggiri yang digunakan pada penelitian ini, dapat dilihat pada tabel 3. Kandungan kalsium untuk produk biskuit dan opak singkong yang ditambahkan tepung tulang ikan tenggiri dapat dilihat pada tabel 4. 
Tabel 4.

Kandungan kalsium produk terbaik

\begin{tabular}{lc}
\hline \multicolumn{1}{c}{ Kandungan Kalsium } & Persentase (\%) \\
\hline Biskuit kontrol & 0,33 \\
Biskuit paling disukai (F3) 5\% & 0,72 \\
Opak singkong kontrol & 0,016 \\
Opak singkong paling disukai (F3) 20\% & 0,131 \\
\hline
\end{tabular}

Tabel 4 menunjukan bahwa biskuit tanpa penambahan tepung tulang tenggiri memiliki kandungan kalsium sebesar 0,33\% (330 mg/100 ml). sedangkan biskuit dengan penambahan tepung tulang tenggiri memiliki kandungan kalsium sebesar 0,72\% (720 mg/100 ml). Opak singkong tanpa penambahan tepung tulang tenggiri memiliki kandungan kalsium sebesar 0,016 \% (16 mg/100 ml) sedangkan opak singkong dengan penambahan tepung tulang tenggiri memiliki kandungan kalsium sebesar $0,131 \%$ (131 mg/100ml).

\section{Pembahasan}

\section{Uji organoleptik}

Pengujian organoleptik dilakukan dengan cara mengisi kuesioner yang meliputi warna, aroma, rasa, tekstur, dan penilaian keseluruhan terhadap kedua jenis produk (biskuit dan opak singkong) dengan penambahan tepung tulang ikan tenggiri.

\section{Biskuit}

\section{Warna}

Warna merupakan penilaian mutu oganoleptik dengan menggunakan indera penglihatan. Berdasarkan pengamatan penelitian yang telah dilakukan, diperoleh hasil warna produk biskuit dari keenam formula adalah kuning kecoklatan. Penilaian Panelis terhadap hasil warna produk biskuit yaitu netral, dimana rata-rata penilaian pada setiap formula berkisar antara 3,60 - 3,68. Biskuit formula 4 merupakan nilai tertinggi yaitu biskuit dengan penambahan tepung tulang ikan tenggiri sebesar 7,5\% memiliki rata-rata sebesar 3,68 yang dinyatakan pada tingkatan Panelis suka terhadap warna biskuit. Sedangkan warna biskuit formula lainnya sama nilai rata-rata sebesar 3,60 yang dinyatakan pada tingkatan Panelis suka terhadap warna biskuit. Penampakan warna pada biskuit yakni berwarna kuning kecoklatan warna kuning kecoklatan tersebut diakibatkan karena adanya reaksi maillard. Reaksi maillard terjadi antara gugusan asam amino dan gula pereduksi yang memberikan warna kecoklatan pada makanan. Reaksi ini terjadi khususnya pada karbohidrat (Winarno, 2004).

\section{Aroma}

Aroma yang dihasilkan dari keenam produk biskuit berbeda-beda. Berdasarkan pengamatan penelitian yang telah dilakukan, diperoleh hasil aroma produk biskuit dari keenam formula berkisar antara agak tidak suka hingga netral. Aroma yang dihasilkan berkisar tidak amis hingga aroma amis khas ikan tenggiri. Hasil uji statistika menunjukan ada perbedaan nyata terhadap aroma ( $p$-value < 0,05). Bau amis ini disebabkan oleh tingginya kandungan protein pada tepung tulang ikan tenggiri yang digunakan sebagai tambahan pembuatan biskuit. Menurut pernyataan (Istanti, 2005), aroma khas ikan juga dikarenakan adanya kandungan protein yang terurai menjadi asam amino khususnya asam glutamat yang dapat memperkuat aroma makanan. Untuk menghilangkan bau amis sebaiknya ditambahkan perlakuan yakni perendaman tulang ikan dengan perasa air jeruk nipis. Dapat disimpulkan bahwa semakain banyak penambahan tepung tulang ikan tenggiri terhadap adonan biskuit, akan semakin mempengaruhi aroma biskuit yang dihasilkan. 


\section{Rasa}

Rasa merupakan penilaian mutu orgnoleptik dengan menggunakan indera pegecap. Rasa yang dihasilkan dari keenam produk biskuit berbeda-beda. Berdasarkan pengamatan penelitian yang telah dilakukan, diperoleh hasil rasa produk biskuit dari keenam formula berkisar antara agak tidak suka hingga netral. Rasa berkisar dari rasa gurih hingga sangat gurih. Hasil pada uji statistika menunjukkan adanya perbedaan nyata penambahan tepung tulang ikan tenggiri terhadap rasa biskuit ( $\mathrm{p}$-value $<0,05$ ). Rasa gurih pada biskuit disebabkan karena adanya kandungan $\mathrm{NaCl}$ dan glutamat yang terdapat pada tepung tulang ikan tengggiri sehingga rasa biskuit menjadi gurih.

Asam glutamat di peroleh dari bahan-bahan yang mengandung banyak protein. Produk ikan yang berasal dari ikan laut memiliki senyawa asam glutamat alami, salah satunya adalah ikan tenggiri. monosodium glutamat merupakan salah satu asam amino yang dapat digunakan pada beberapa produk dari ikan laut. Dapat disimpulkan bahwa semakin banyak penambahan tepung tulang ikan tenggiri pada biskuit, maka rasa yang dihasilkan semakin gurih.

\section{Tekstur}

Tekstur merupakan penilaian mutu orgnoleptik dengan menggunakan indera peraba. Berdasarkan pengamatan penelitian yang telah dilakukan, diperoleh hasil tekstur produk biskuit dari keenam formula berkisar antara renyah sampai tidak renyah. Hasil uji statistika menunjukkan ada perbedaan nyata terhadap tekstur ( $\mathrm{p}$-value $<0,05$ ). Tekstur yang agak keras ini diduga karena didalam tepung tulang ikan tenggiri banyak kandungan kalsium sehingga tekstur menjadi agak keras. Hal ini sesuai dengan pernyataan rusky pratama dkk (2014) yang menyatakan bahwa semakin besar jumlah penambahan tepung tulang ikan pada biskuit maka tingkat kekerasan biskuit cenderung semakin meningkat. Dapat disimpulkan bahwa semakin banyak penambahan tepung tulang ikan tenggiri pada biscuit maka tekstur biskuit yang dihasilkan akan semakin keras, hal ini diduga karna ada nya kandungan kasium.

\section{Penerimaan keseluruhan}

Penerimaan keseluruhan yaitu nilai yang diberikan dari Panelis terhadap sampel biskuit yang di uji berdasarkan seluruh parameter yang ada sebelumya, seperti warna, aroma, rasa dan tekstur. Penerimaan keseluruhan dapat mengetahui sampel mana yang disukai oleh Panelis yang kemudian akan dipakai sebagai acuan untuk memilih formulasi yang terbaik dari keseluruhan sampel biskuit. Penilaian uji organoleptik terhadap penilaian keseluruhan biskuit dengan memberikan nilai pada kuesioner uji organoleptik. Hasil uji statistik memperlihatkan ada perbedaan nyata terhadap penerimaan keseluruhan biskuit ( $\mathrm{p}$-value $<0,05$ ). Hal ini diduga karena warna, aroma, rasa dan tekstur biskuit yang dihasilkan berbeda-beda. Perlu adanya penelitian lebih lanjut tentang penambahan tepung tulang ikan tenggiri terhadap produk makanan lain yang lebih menarik dan diminati, sehingga masyarakat mampu mengolah tulang ikan tenggiri menjadi olahan makanan olahan lain yang tidak hanya meningkatkan nilai gizinya tetapi juga memiliki daya jual yang lebih baik.

\section{Opak singkong}

\section{Warna}

Warna opak singkong berkisar dari putih kekuningan hingga berwarna coklat. Berdasarkan hasil uji organoleptik dapat dilihat bahwa dari keenam formula opak singkong dengan penambahan tepung tulang ikan tenggiri yang dihasilkan tingkat warna dengan nilai rata-rata tertinggi yaitu pada formula 1, yaitu tanpa penambahan tepung tulang ikan tenggiri sebesar $(4,13)$ yang termasuk dalam katagori suka, hal ini 
dikarenakan pada formula 1 memiliki warna yang lebih cerah yaitu putih kekuningan dibandingkan dengan formula lainya yang semakin coklat. Sedangkan nilai rata-rata opak singkong terendah pada formula 6 dengan penambahan tepung tulang ikan tenggiri sebanyak 50\% yakni sebesar (3.87) dengan katagori suka. Warna yang dihasilkan oleh formula 6 adalah berwarna coklat, hal ini diduga karena konsentrasi pemberian tepung tulang ikan tenggiri yang terlalu banyak yang mengakibatkan warna menjadi lebih coklat dan tidak cerah sehingga berkesan kurang menarik bagi Panelis.

Tepung tulang ikan mengandung protein dan gula peredukasi yang mengalami reaksi mailard jika dipanaskan (Tababaka (2004) dalam (M. Ryo Andika Putra, et al., 2015) Tingginya kandungan mineral dalam suatu bahan makanan akan mempengaruhi warna produk yang dihasilkan (Aryani, 2012 dalam Herpandi dkk., 2015). Warna yang semakin coklat ini dikarenakan semakin tinggi produk chips yang ditambahkan tepung tulang ikan maka semakin coklat warna yang dihasilkan, oleh karena itu warna yang paling banyak disukai Panelis yaitu pada formula 1 karena warna yang dihasilkan lebih menarik dibandingkan dengan formula lainya yang ditambahkan tepung tulang ikan tenggiri.

\section{Aroma}

Timbulnya aroma karena adanya zat volatil (mudah menguap), sedikit larut air dan lemak. Nilai rata-rata aroma opak singkong dengan penambahan tepung tulang ikan tenggiri sebesar 3,65-3,85. Aroma ini berkisar dari tidak beraroma atau hambar hingga gurih keamisan. Nilai rata-rata tertinggi atau yang paling disukai, yaitu opak singkong formula 3 dan 4 sebesar $(3,85)$ dengan katagori suka. Hal ini diduga karena aroma yang dihasilkan oleh formula 3 gurih khas ikan dan tidak terlalu menyengat. Sedangkan nilai rata-rata terendah atau penilaian yang paling tidak disukai yaitu formula 6 sebesar $(3,65)$ dengan katagori suka. Hal ini diduga aroma yang dihasilkan oleh Opak singkong formula 6 sangat amis sehingga Panelis kurang menyukai aroma Opak singkong tersebut. Formula 3 adalah Opak singkong dengan penambahan tepung tulang ikan tenggiri sebanyak $20 \%$ sedangkan formula 6 menggunakan tepung tulang ikan tenggiri sebanyak $50 \%$.

Aroma amis dipengaruhi oleh bahan baku yang digunakan yaitu tepung tulang ikan tenggiri yang memilki aroma amis. Aroma khas ikan juga dipengaruhi adanya kandungan protein yang terurai menjadi asam amino khususnya asam glutamat yang dapat memperkuat aroma makanan (Istanti, 2005). Sedangkan, Penambahan tepung tulang ikan memberikan pengaruh nyata pada tingkat kesukaan aroma dari produk yang dihasilkan (Didi , et al., 2013). Hal ini diduga karena semakin banyak penamabahan tepung tulang ikan maka semakin tercium aroma kas ikan pada produk. Ismanadji dkk. tahun 2000 dalam (Maulida , 2005) menyatakan bahwa aroma yang dihasilkan dari suatu produk dengan penambahan tepung tulang ikan, tergantung dari banyaknya tepung tulang ikan. Semakin tinggi tingkat konsentrasi penambahan tepung tulang ikan maka semakin menurun tingkat kesukaan Panelis atas aroma produk karena bau amis ikan. Untuk menghilangkan bau amis pada tepung tulang ikan tenggiri sebaiknya dilakukan perendaman dengan air perasan jeruk nipis. Menghilangkan bau amis perlu adanya perendaman dengan larutan jeruk nipis (Sa'adah, 2013).

\section{Tekstur}

Teksur adalah penilaian mutu organoleptik secara subyektif menggunakan panca indera perasa. Hasil penilaian tekstur pada keenam formula Opak singkong dengan penambahan tepung tulang ikan tenggiri. Tekstur Opak singkong ini berkisar antara keras sampai dengan renyah. Penilaian tingkat kesukaan yang dinilai dengan nilai rata-rata teringgi yaitu pada formula 5 sebesar $(3,84)$ dengan katagori suka. Hal ini dikarenakan formula 6 memiliki tekstur yang lebih renyah dibandingkan formula lainnya. Sedangkan, 
nilai rata-rata terendah pada formula 1 sebesar $(3,53)$ dengan katagori suka. Pada formula 1 tekstur yang dihasilkan lebih keras di bandingkan dengan formula lainnya yang ditambahkan dengan tepung tulang ikan tenggiri sehingga Panelis tidak menyukai opak singkong pada formula tersebut.

Penambahan tepung tulang ikan membuat produk renyah dikarenakan tepung tulang ikan tenggiri mengandung protein yang tinggi. Pada tulang ikan tenggiri memiliki kandungan protein, protein memiliki kemampuan untuk mengikat komponen lain seperti air dan lemak. Kemampuan mengikat air ini dikarenakan oleh sifat gugus asam amino yang hidrofilik (suka air) dan ikatan hidrogen menyatakan bahwa sifat fungsional protein bergantung pada keterikatan protein dengan air. Selain dari kandungan protein kandungan pati pada bahan pangan mempengaruhi tekstur pada produk. Hasil penelitian herpandi, dkk. menjelaskan bahwa penambahan tepung tulang ikan gabus pada kerupuk berpengaruh nyata terhadap persentase pengembangan kerupuk tulang yang dihasilkan. Hal ini diduga karena banyaknya penambahan tepung tulang sehingga menyebabkan menurunnya kandungan pati dan amilopektin pada tepung tapioka. Oleh karena itu, semakin tinggi penambahan tepung tulang ikan, maka semakin renyah hasil chips yang dihasilkan (M. Ryo Andika Putra, et al., 2015).

\section{Rasa}

Rasa merupakan atribut sensori yang tidak dapat dilepaskan dari keseluruhan cita rasa pangan. Rasa adalah sensasi oleh alat pengecap yang berada di dalam rongga mulut. Rasa pada Opak singkong ini berkisar dari hambar sampai sangat gurih. Nilai rata-rata uji organoleptik opak singkong berkisar antara 3.47 - 3,89. Tingkat rasa yang paling disukai yaitu formula 3 dengan nilai rata-rata $(3,89)$ yang dikatagorikan suka. Formula 3 ini memiliki rasa gurih yang khas ikan sehingga Panelis lebih menyukai rasa pada formula 3.

Penilaian rasa yang terendah yaitu pada formula 6 dengan nilai rata-rata sebesar $(3,47)$ dengan kategori biasa saja. Formula 6 memiliki rasa yang gurih lebih keasinan, sehingga Panelis kurang menyukai rasa yang dihasilkan oleh formula 6. Adanya rasa gurih keasinan disebabkan karena adanya kandungan asam glutamat yang terdapat pada tepung tulang ikan tengggiri sehingga rasa opak singkong menjadi gurih. Asam glutamat di peroleh dari bahan-bahan yang mengandung banyak protein. Produk ikan yang berasal dari ikan laut memiliki senyawa asam glutamat alami, salah satunya adalah ikan tenggiri. Monosodium glutamat merupakan salah satu asam amino yang dapat digunakan pada beberapa produk dari ikan laut. Penambahan tepung tulang ikan tenggiri pada Opak singkong yang semakin tinggi penambahannya akan mempengaruhi rasa produk, produk yang dihasilkan akan semakin terasa asin maka semakin tinggi penambahan tepung tulang ikan tenggiri pada pengolahan Opak singkong penilaian Panelis yaitu semakin rendah.

\section{Penerimaan keseluruhan}

Penerimaan keseluruhan merupakan nilai yang diberikan Panelis terhadap sampel opak singkong yang ditambahkan dengan tepung tulang ikan tenggiri yang diuji berdasarkan seluruh parameter yang ada sebelumnya, seperti warna, aroma, tekstur dan rasa. Keenam formula opak singkong dengan penambahan tepung tulang ikan tenggiri yang dihasilkan tingkat penerimaan keseluruhan yang paling disukai, yaitu opak singkong formulasi 3 dengan penambahan tepung tulang ikan tenggiri 20\% memiliki nilai rata-rata 3,99 yang dikategorikan suka. Formula 3 disukai oleh Panelis karena aroma yang gurih dan rasa yang khas ikan.

Penerimaan keseluruhan tingkat kesukaan terendah yaitu pada formula 6 dengan nilai rata-rata sebesar $(3,52)$ dengan katagori suka. Formula 6 memiliki nilai terendah dikarenakan warna opak coklat, aroma sangat amis, rasa yang asin. Formula 6 merupakan opak singkong dengan penambahan tepung tulang ikan tenggiri sebanyak 50\%. Perbedaan penilaian Panelis terhadap uji organoleptik ini diduga karena dari 
segi warna formula 1 lebih menarik dibanding dengan formula lainya, aroma yang dihasilkan formula 3 khas ikan sedangkan pada formula 6 aroma khas ikan lebih tercium amis, sehingga Panelis tidak menyukainya, dari tektur yang dihasilkan pada formula 6 lebih renyah dibanding dengan formula lainya dan dari segi rasa formula 3 lebih gurih khas ikan dibanding dengan formula 3.oleh karena itu penilaian tertinggi atau yang paling disukai dari opak singkong dengan penambahan tepung tulang ikan tenggiri yaitu pada formula 3.

\section{Analisis kandungan gizi}

Hasil uji proksimat tepung tulang ikan tenggiri dalam 100 gr menunjukkan bahwa terdapat kandungan air sebesar $1.2885 \mathrm{gr}$, abu sebesar $27.4938 \mathrm{gr}$, kandungan protein di dalam tepung tulang ikan tenggiri cukup tinggi yakni sebesar 40.3551 gr. Kandungan lemak sebesar 21.5128 gr dan karbohidrat 4.7713 gr. Berdasarkan penelitian yang telah dilakukan didapatkan hasil kalsium tepung tulang ikan tenggiri sebesar 0,403 gr atau setara dengan $403 \mathrm{mg}$.

Kadar kalsium formula 3 (biskuit yang ditambahkan tepung tulang ikan tenggiri sebanyak 5\%) lebih besar dari formula 1 (biskuit tanpa penambahan tepung tulang ikan tenggiri). Terjadinya peningkatan kandungan kalsium pada biskuit yang paling disukai (formula 3) 0,039 gr per 100 gram dibandingkan dengan biscuit tanpa penambahan tepung tulang ikan tenggiri. Kandungan kalsium formulasi 1 (biskuit tanpa penambahan tepung tulang ikan tenggiri) sebesar 0.033 gr dan kandungan kalsium formulasi 3 (biskuit yang ditambahkan tepung tulang ikan tenggiri sebanyak 5\%) mengalami peningkatan kadar kalsium sebesar 0.072 gr. Asupan kalsium yang cukup untuk remaja dan dewasa adalah sekitar 1000-1300 mg / hari Biskuit dengan penambahan tepung tulang ikan mempunyai kandungan kalsium yang tinggi dan baik digunakan untuk PMT (pemberian makanan tambahan). Biskuit dengan penambahan tepung tulang ikan tenggiri sangat baik untuk dikembangkan guna meningkatkan asupan gizi kalsium dari konsumsi biskuit.

Kadar kalsium pada Opak singkong formula 3 (dengan penambahan tepung tulang ikan tenggiri $20 \%$ ) lebih besar dari formula 1 (tanpa penambahan tepung tulang ikan tenggiri). Kandungan opak singkong pada formula satu sebesar $0.016 \%$, sedangkan formula 3 sebesar $0,131 \%$. Hal ini diduga adanya pengaruh penambahan tepung tulang ikan tenggiri terhadap opak singkong. Hasil uji kalsium tepung tulang ikan tenggiri mengandung kalsium yaitu sebesar $0,403 \%$. Sehingga, dapat disimpulkan bahwa opak singkong yang ditambahkan tepung tulang ikan tenggiri memiliki kandungan kalsium yang tinggi.

\section{Simpulan dan saran}

Konsentrasi penambahan tepung tulang ikan tenggiri yang paling disukai pada produk biskuit didapat pada formula 3 dengan konsentrasi penambahan tepung tulang ikan tenggiri sebesar 5\% dan opak singkong didapat pada formula 3 dengan konsentrasi penambahan tepung tulang ikan tenggiri sebesar $20 \%$. Kandungan kalsium pada produk biskuit formula 3 (5\%) sebesar 0,72\% dan opak singkong formula 3 (20\%) sebesar $0,131 \%$. Pada pembuatan tepung tulang ikan tenggiri sebaiknya dilakukan perendaman dengan larutan jeruk nipis terlebih dahulu agar dapat mengurangi aroma amis dan perlu dilakukan penelitian lebih lanjut mengenai penambahan tepung tulang ikan tenggiri terhadap produk makanan lain, seperti mie, siomay dan produk lainnya.

\section{Referensi}

Badan Litbangkes Kemenkes R.I. (2013). Pedoman pewawancara Petugas pengumpul data Riset Kesehatan Dasar (Riskesdas) 2013. Jakarta: Badan Litbangkes Kemenkes RI. 
Badan Pusat Statistik Provinsi Lampung. (2017). Produksi perikanan tangkap menurut Kabupaten/Kota dan Subsektor di Provinsi Lampung (ton) 2016. Retrieveved from https://lampung.bps.go.id/dynamictable/html diakses tanggal 26 Desember 2017.

Depkes RI. (2006). Profil kesehatan Indonesia. Jakarta: Depkes RI.

Didi, I. B., Asri , S. . N. \& Nikmawati, S. Y. (2013). Pengaruh penambahan tepung tulang ikan tuna terhadap karakteristik hedonik kue bagea khas Gorontalo. Jurnal Ilmiah Perikanan dan Kelautan, Volume 1(2), 8180., Retrieved from http://ejurnal.ugn.ac.id/index.php/nike.

Istanti, I. (2005). Pengaruh lama penyimpanan terhadap karakteristik kerupuk ikan sapu-sapu. Skripsi. Program Sarjana, Institut Pertanian Bogor.

M. Ryo Andika Putra, A. M. R., Rodiana, N. \& Herpandi. (2015). Fortifikasi tepung tulang ikan gabus (channa striata) pada kerupuk sebagai sumber kalsium. Jurnal Teknologi Hasil Perikanan. Volume 4(2), 128 - 139, Retrieved from https://ejournal.unsri.ac.id/index.php/fishtech/article/view.

Maulida, N. (2005). Pemanfaatan tepung tulang ikan madidihang (thunnus albacares) sebagai siplemen dalam pembuatan biskuit (creakers), Skripsi. Fakultas Perikanan dan Ilmu Kelautan. Institut Pertanian Bogor.

Nugrahani, P. (2014). Latihan jalan tandem lebih baik dari pada latihan dengan menggunakan swiss ball terhadap peningkatan Keseimbangan untuk mengurangi resiko jatuh pada lanjut usia (Lansia). Jurnal Fisioterapi, Volume 14(2).

Sa'adah, U. (2013). Daya terima dan komposisi proksimat tepung tulang ikan lele yang mengalami proses perendaman dalam larutan jeruk. Skripsi. Fakultas Ilmu Kesehatan Universitas Muhamadiyah Surakarta, Solo, Retrieved from http://eprints.ums.ac.id/27243/1/.

Sulaiman, S. \& Noor, Z. (1982). Pengaruh asam cuka terhadap rasa amis dari daging ikan mujair yang dipanggang. Jurnal Agritech, Volume 3(4).

Waluyani, D. O. (2012). Makanan super ini bernutrisi tinggi. Detik Media. Retrived Januari 28, 2013, from http://food.detik.com/read/2012/04/20/172637/1897627/900/5.

Winarno, F. G. (1997). Kimia pangan dan gizi. Jakarta: PT. Gramedia Pustaka Utama.

Winarno, F. G. (2004). Ilmu pangan dan gizi. Jakarta: Gramedia Pustaka Utama. 